\title{
COMPARATIVE DYNAMIC ANALYSIS OF VALUE ADDED CREATED BY INDUSTRY “CROP AND ANIMAL PRODUCTION, HUNTING AND RELATED SERVICE ACTIVITIES" IN THE BALTIC STATES AND FINLAND
}

\author{
Andrejs Jaunzems, Ilze Balode \\ Ventspils University of Applied Sciences, Latvia \\ jaunzems@venta.lv
}

\begin{abstract}
The goal of this paper is to carry out the comparative dynamic analysis of value added as part of gross output created by the industry A01 (Crop and animal production, hunting and related service activities) in the Baltic States and Finland in the period of 2000-2014. The empirical material of the study is the National InputOutput Tables for the Period 2000-2014 available on the World Input-Output Database with its unified structured statistical information in monetary terms. The main theoretical tool is the original version of the Input-Output model created by the authors that allows to calculate and interpret the interindustry coefficients, Leontief inverse, allocation coefficients, Ghosh inverse. The time series of value added as part of gross output in the industry A01 are investigated. Although this indicator decreases in all examined countries, the comparative approach allows us to identify sufficient differences in the industry's A01 value added formation in the respective countries. The Input-Output model allows us to provide holistic investigation of the industry's A01 one monetary unit gross output production costs dynamics. The discussion part of the paper is devoted to identifying the most important reasons for differences in economic efficiency (in the sense of value added creation) of the industry A01 in the Baltic States and Finland. We define the objective and other reasons, which cause average cost increase in all examined countries. We also identify the differences in the structure of average cost vectors, which indicate historically formed and existing technological differences in A01 economy.
\end{abstract}

Keywords: industry A01, value added, Input-Output model, interindustry coefficients, Leontief inverse, allocation coefficients, Ghosh inverse.

\section{Introduction}

The value added creation problems in agriculture are investigated in line with a number of recent papers on this issue, for instance, Projecting value added in agriculture in Latvia (Pilvere, Krievina, Nipers 2018) devoted to the value added increase problem in connection with the Common Agricultural Policy of the European Union. It suggests the following main conclusion: "If the Common Agricultural Policy of the European Union is not changed after 2020 (baseline scenario), the value added of agriculture in Latvia is expected to increase by $33 \%$ in 2030 and by $80 \%$ in 2050 when compared with 2017". We apply the Input-Output models presented in The Input-Output analysis of blue industries: comparative study of Estonia and Finland (Ashyrov, Paas, Tverdostup 2018). The authors employ the Input-Output methodology to analyse the inter-industry linkages based on the Input-Output tables.

The aim of the paper is to carry out a dynamic comparative analysis of value added as part of gross output created by the industry A01 (Crop and animal production, hunting and related service activities) in the Baltic States and Finland in the period of 2000-2014 in order to find answers to the following questions: "What causes the Latvian industry's A01 low efficiency (in the sense of value added creation) when compared with other examined countries? How realistic is it to achieve a significant A01 value added increase in Latvia in the nearest years?" In order to identify the objective similarity and historically formed differences in A01 economy, a comparative analysis of the A01 average cost vectors' structure is provided. Besides that we examine the impact of A01 final demand growth and A01 value added growth on the national economy in general.

The empirical material of the study is the National Input-Output Tables for the Period 2000-2014 (NIOT) available via the World Input-Output Database (WIOD) with their unified structured statistical information in monetary terms (www.wiod.org). According to NIOT the United Nations 3-letter codes are used: EST (Estonia), FIN (Finland), LVA (Latvia), LTU (Lithuania). Data for 56 sectors are classified according to the International Standard Industrial Classification of All Economic Activities (ISIC), revision No. 4. The ISIC is the United Nations industry classification system. ISIC revision No. 4 applies a number of criteria such as input, output and use of the products produced, and places additional emphasis on the production processes. 
The products in NIOT are classified according to the statistical classification of products by activity, abbreviated as CPA. The statistical classification of products by activity in the European Economic Community is a product nomenclature structured according to their industrial origin. It is harmonized with other Community classifications of activities and products: NACE revision No. 1, PRODCOM and the Combined Nomenclature, and with the corresponding United Nations classifications. The CPA comprises the legal basis for the classification and the explanatory notes. The NIOT classification of products (goods and services) covers 56 product categories following the primary outputs from 56 sectors. The NIOT are compiled in current prices, expressed in millions of US dollars. The Input-Output tables have an industry-by-industry format and reflect the economic linkages across industries in the form of direct and dual systems of accounting balancing equations. We would like to stress that the authors have accepted the NIOT as a reliable source of information and the NIOT are deemed in the current research as indisputable. The most recent NIOT available refer to 2014.

The general theoretical background of the current study in the wide sense is the classical InputOutput analysis offered by Leontief [1] and Ghosh [2]. The current content of the Input-Output analysis is explored, for example, in Input-Output Analysis. Foundations and Extensions by Ronald E. Miller and Peter D. Blair [3], and in a number of academic publications (see, for example, Rose, Miernyk 1989).

The main conclusion about the reasons of the comparative inefficiency of the Latvian industry A01: direct backward linkage of the industry A01 in Latvia is higher than in the referred countries, namely, production of one monetary unit of gross output requires in LVA bigger intermediate expenses when compared with EST, FIN, LTU. If industry's A01 management in Latvia is able to adopt better controlling patterns from foreign countries, it will result in value added as part of gross output increase. The industry A01 is a private business industry which in general terms operates in the global perfect competition market environment. Due to the pressure of competition industry's A01 producers will, sooner or later, adopt the most efficient technical methods of production. The analysis of the final demand increase utilizes the industry's A01 total backward domestic linkage. The conclusion: to ensure an economic equilibrium, the A01 final product growth, when all other industries' final products remain unchanged, requires significant balanced growth of domestic industries gross outputs. A similar conclusion follows from the calculated total forward linkage: to ensure economic equilibrium the A01 value added growth, when all other industries' value added remain unchanged, requires significant balanced growth of domestic industries gross outputs. Such balanced growth of the national industries gross outputs may be feasible solely as a result of long-term economical evolution.

Note. All tables and all figures in the current paper are created by the authors by applying NIOT data, mathematical models and Microsoft Excel tools.

\section{Materials and methods}

As mentioned in the introduction, the empirical material of the study is the National Input-Output Tables for the Period 2000-2014 (NIOT) available via the World Input-Output Database (WIOD) with their unified structured statistical information in monetary terms (www.wiod.org). The theoretical framework and methodology of our study to identify the most important reasons, which cause the similarity and differences in the value added formation in the industry A01 in EST, FIN, LVA, LTU (in the sense of value added creation power), are directly connected with the content of the paper by Jaunzems (2018), where the original Input-Output model as adapted for NIOT is offered and the research methodology was approbated.

Let us shortly explain the theoretical Input-Output framework, key concepts, and methods used in connection with the structure of the given NIOT information.

We assume that the open economy is categorized into $\mathrm{n}$ sectors (industries). The Input-Output price model based on monetary data in current prices is constructed by utilizing the national account's balancing direct and dual equations. Thijs ten Raa (2019) wrote: "I consider the case of small open economy. In such an economy, all products are priced by the international terms of trade and, 
therefore, all industries are machines transforming factor inputs into value added. In other words, industries have multiple (factor) inputs, but essentially a single "output", namely value added."

Generally speaking, we agree with such an interpretation of industry. However, there are some distinctions in our interpretation when compared with interpretation of Thijs ten Raa. We consider the industry as the abstract subject-producer transforming multiple factor inputs into gross output that is sold generating value added. The macroeconomic concept of value added created by an industry is explained in the European Central Bank (ECB) Glossary [9]: "value added (gross) is total output less the intermediate consumption". Eurostat definition [10;11]: "GDP = compensation of employees + gross operating surplus + net taxes on production and imports." It should be noted that WIOD does not explore the structure of value added which is a substantial deficiency, because it makes impossible to know the distribution of created wealth between economic agents.

Value added generated by industry equals to the expenditures for the primary resources. Value added ensures payments for labour, payments to the owners of land, to the owners of factories, to the money lenders, and to the government as well. Naturally, all these economic agents want more money, nevertheless, the rates of payments are determined by multiform relations between agents in the concrete political, economic, social, technological, international, legal and bio (PESTILB) environment.

The Input-Output model exposes the holistic logic of the definitions given by the ECB and Eurostat.

The comparative approach allows us to recognize differences and analogies in the structure and dynamics of the industry A01 average costs vectors and in the structure of average revenues vectors, as well. We can observe, for example, the substantial differences in the A01 intermediate purchases from the industry D35 (electricity, gas, steam and air conditioning supply). The relevant differences between the relevant interindustry coefficients and allocation coefficients, and the relevant elements of the Leontief inverse and Ghosh inverse as well in corresponding industries explain the differences of value added creation power. Further investigation is needed together with industry A01 experts and must be oriented towards explaining the most essential differences between the line of indicators in order to clarify PESTILB environment and elaborate upgraded management decisions.

So, we consider the industry as the abstract subject-producer transforming multiple factor inputs into gross output what being sold generates value added. In order to produce gross output, the industry has to buy intermediate domestic or imported resources and, respectively, intermediate expenses rise. In order to get money the industry as an abstract subject-producer must sell its gross output. What are the potential buyers? Sales revenues of the industry consist from money received from domestic industries and money received from the final demander. Therefore, industry acts in the market environment like an oligopoly firm, because the winnings from strategic decision depend on behaviour of other industries and final demanders. Besides that the industry acts as a global price taker, therefore relevant products' world price dynamics crucially exerts the industry's economic behaviour.

Let us demonstrate conditions necessary for each industry. Consider, for example, industry A01 as industry No 1 .

1. The A01 payments balancing equation (vertical):

$$
d_{11} x_{1}+d_{21} x_{1}+\ldots+d_{n 1} x_{1}+m_{11} x_{1}+m_{21} x_{1}+\ldots+m_{n 1} x_{1}+G V A_{1}=x_{1} .
$$

The sum of intermediate consumption expenditures plus gross value added equals the value of gross output. Here $x_{1}$ is the gross output in the industry A01, $d_{i 1}$ is the i-th domestic interindustry coefficient, $m_{i 1}$ is the coefficient of $i$-th imported resources intermediate consumption, $G A_{1}$ is the gross value added in the industry A01.

2. The industry's A01 revenues balancing equation (horizontal):

$$
d_{11} x_{1}+d_{12} x_{2}+\ldots+d_{1 n} x_{n}+F D_{1}=x_{1} \text {. }
$$

Here $\left(x_{1}, x_{2}, \ldots, x_{n}\right)$ is the national economy gross output in vectorial form, $\mathrm{FD}_{1}$ is the part of the A01 gross output sold to the final consumers. The most important parts of the final demand are the CONS_h (Final consumption expenditure by households), CONS_g (Final consumption expenditure by government), EXP (Exports), GFCF (Gross fixed capital formation). 
Note 1 . Thijs ten Raa (2019) interprets the industry as a producer who has "essentially a single "output", namely value added". In some sense we agree with that. If we assume that industry wants to maximize value added, equations 1, 2 discussed above demonstrate the complicate global environment where industry makes decision about its gross output. Obviously, there is extensive uncertainty, lot of factors that are out of industry's control. Of course, some indicators can be managed. For example, if producers of the industry implement the lean economics' idea in order to improve their technologies, it will definitely result in value added increase per monetary unit of gross output. If industry has week total backward and total forward linkages to the rest industries (what take place, for example, in case of industry P85 (Education) in the Baltic States), then it is possible to increase gross output and value added by stimulating the export component of final demand.

Note 2. Economists of the industry A01 are more concerned about chances to get revenue

$$
d_{11} x_{1}+d_{12} x_{2}+\ldots+d_{1 n} x_{n}+F D_{1}
$$

than about the perspectives of purchases

$$
d_{11} x_{1}+d_{21} x_{1}+\ldots+d_{n 1} x_{1}+m_{11} x_{1}+m_{21} x_{1}+\ldots+m_{n 1} x_{1} .
$$

Note 3. The Leontief inverse is useful for holistic analysis because the first column of the Leontief inverse describes the necessary increase in domestic output and import to provide the balanced increasing of the final product of A01 by one monetary unit, when all other industries' added values remain unchanged. Such information allows us to estimate the likelihood of the final product increase. For instance, if the impact on domestic output or impact on the import from such action is unrealistically big, then action is not likely. If the impact is relatively small, then managers have to study the sales problem.

Note 4. The Gosh inverse is useful for holistic analysis because the first column of the Ghosh inverse describes the necessary increase in domestic output to provide the balanced increasing of the A01 value added by one monetary unit, when all other industries' added values remain unchanged. Such information allows us to estimate the likelihood of A01 value added increase.

\section{Results and discussion}

The inward logic and consistency of the research are the following. The industry's A01 value added increase can be attained: (a) as a result of average cost (input) with respect to monetary unit of gross output decreasing or (b) as a result of gross output increase. The solution (a) is possible, if industry's A01 management in Latvia is able to adopt better control patterns from foreign countries and to implement the principles of the lean economics. The solution (b) is possible, if: (b1) the gross output increase in A01 does not require through interindustry links unrealistic increasing of the rest of national economy; (b2) is possible to expand sufficiently the final demand of A01 product.

The materials and methods examined before allow us to examine the conditions (a) and (b) in the Latvian case. In order to get a complete view on the industry's A01 economics in EST, FIN, LVA, LTU the line of indicators is calculated. It should be emphasised that the interpretations of indicators used are based on the holistic mathematical connections resulting from the Input-Output model as a whole.

The economic analysis leads to the main conclusion: the most realistic tool to increase value added in the Latvian A01 is managerial and technical improvement of production in order to decrease the average cost with respect to monetary unit of output (solution (a)). Industry's management in Latvia must adopt better technical and control patterns from foreign countries. Increasing A01 value added with help of gross output increase (solution (b)) seems to be unrealistic due to relatively big total backward and total forward linkages from A01 to the rest national economy. It could be possible as a result of long-term Latvian economy evolution.

Note. It is practicable to use the code of industries in the text. In spite of the limited volume of the paper the code and descriptions used in NIOT for the reader's convenience are given in Table 1. The industries in NIOT according to the International Standard Industrial Classification are strongly defined and international. The authors consider that employing the NIOT codes on a regular basis would be reasonable for more unified and precise scientific understanding of each industry's notion. 
NIOT industries' codes and descriptions

Table 1

\begin{tabular}{|c|c|}
\hline Code & Description \\
\hline A01 & Crop and animal production, hunting and related service activities \\
\hline $\mathrm{A} 02$ & Forestry and logging \\
\hline A03 & Fishing and aquaculture \\
\hline $\mathrm{B}$ & Mining and quarrying \\
\hline $\mathrm{C} 10-\mathrm{C} 12$ & Manufacture of food products, beverages and tobacco products \\
\hline $\mathrm{C} 13-\mathrm{C} 15$ & Manufacture of textiles, wearing apparel and leather products \\
\hline $\mathrm{C} 16$ & Manufacture of wood and of products of wood and cork, except furniture; manufacture of articles of straw and plaiting materials \\
\hline $\mathrm{C} 17$ & Manufacture of paper and paper products \\
\hline $\mathrm{C} 18$ & Printing and reproduction of recorded media \\
\hline $\mathrm{C} 19$ & Manufacture of coke and refined petroleum products \\
\hline $\mathrm{C} 20$ & Manufacture of chemicals and chemical products \\
\hline $\mathrm{C} 21$ & Manufacture of basic pharmaceutical products and pharmaceutical preparations \\
\hline $\mathrm{C} 22$ & Manufacture of rubber and plastic products \\
\hline $\mathrm{C} 23$ & Manufacture of other non-metallic mineral products \\
\hline $\mathrm{C} 24$ & Manufacture of basic metals \\
\hline $\mathrm{C} 25$ & Manufacture of fabricated metal products, except machinery and equipment \\
\hline $\mathrm{C} 26$ & Manufacture of computer, electronic and optical products \\
\hline $\mathrm{C} 27$ & Manufacture of electrical equipment \\
\hline $\mathrm{C} 28$ & Manufacture of machinery and equipment n.e.c. \\
\hline $\mathrm{C} 29$ & Manufacture of motor vehicles, trailers and semi-trailers \\
\hline $\mathrm{C} 30$ & Manufacture of other transport equipment \\
\hline C31_C32 & Manufacture of furniture; other manufacturing \\
\hline $\mathrm{C} 33$ & Repair and installation of machinery and equipment \\
\hline D35 & Electricity, gas, steam and air conditioning supply \\
\hline E36 & Water collection, treatment and supply \\
\hline E37-E39 & $\begin{array}{l}\text { Sewerage; waste collection, treatment and disposal activities; materials recovery; remediation activities and other waste } \\
\text { management services }\end{array}$ \\
\hline $\mathrm{F}$ & Construction \\
\hline G45 & Wholesale and retail trade and repair of motor vehicles and motorcycles \\
\hline G46 & Wholesale trade, except of motor vehicles and motorcycles \\
\hline G47 & Retail trade, except of motor vehicles and motorcycles \\
\hline H49 & Land transport and transport via pipelines \\
\hline $\mathrm{H} 50$ & Water transport \\
\hline H51 & Air transport \\
\hline H52 & Warehousing and support activities for transportation \\
\hline H53 & Postal and courier activities \\
\hline I & Accommodation and food service activities \\
\hline $\mathrm{J} 58$ & Publishing activities \\
\hline J59_J60 & $\begin{array}{l}\text { Motion picture, video and television programme production, sound recording and music publishing activities; programming and } \\
\text { broadcasting activities }\end{array}$ \\
\hline J61 & Telecommunications \\
\hline J62_J63 & Computer programming, consultancy and related activities; information service activities \\
\hline K64 & Financial service activities, except insurance and pension funding \\
\hline K65 & Insurance, reinsurance and pension funding, except compulsory social security \\
\hline K66 & Activities auxiliary to financial services and insurance activities \\
\hline L68 & Real estate activities \\
\hline M69_M70 & Legal and accounting activities; activities of head offices; management consultancy activities \\
\hline M71 & Architectural and engineering activities; technical testing and analysis \\
\hline M72 & Scientific research and development \\
\hline M73 & Advertising and market research \\
\hline M74_M75 & Other professional, scientific and technical activities; veterinary activities \\
\hline $\mathrm{N}$ & Administrative and support service activities \\
\hline O84 & Public administration and defence; compulsory social security \\
\hline P85 & Education \\
\hline Q & Human health and social work activities \\
\hline R_S & Other service activities \\
\hline
\end{tabular}




\section{Excerpts from the NIOT 2014 concerning industry's A01 expenditures and revenues in} current prices, expressed in millions of US dollars.

Tables 2 and 3 contain the general indicators that describe A01 intermediate consumption.

Table 2

Industry's A01 expenditures in EST, FIN, LVA, LTU

\begin{tabular}{|c|l|c|c|c|r|}
\hline Code & Description & EST & FIN & LVA & \multicolumn{1}{|c|}{ LTU } \\
\hline- & Intermediate consumption (domestic) & 453.54 & 3247.52 & 708.17 & 1138.27 \\
\hline- & Intermediate consumption (imports) & 249.87 & 1021.59 & 558.31 & 929.53 \\
\hline II_fob & Total intermediate consumption & 703.41 & 4269.11 & 1266.48 & 2067.80 \\
\hline GVA & Gross value added at basic prices & 519.78 & 2190.05 & 538.27 & 1398.69 \\
\hline VA & Net value added at basic prices & 456.51 & 2044.56 & 451.09 & 1264.87 \\
\hline GO & Output at basic prices & 1223.19 & 6459.17 & 1804.75 & 3466.50 \\
\hline
\end{tabular}

Table 3

Industry's A01 expenditures in EST, FIN, LVA, LTU with respect to monetary unit of output

\begin{tabular}{|c|l|c|c|c|c|}
\hline Code & Description & EST & FIN & LVA & LTU \\
\hline- & Intermediate consumption (domestic) & 0.3708 & 0.5028 & 0.3924 & 0.3284 \\
\hline- & Intermediate consumption (imports) & 0.2043 & 0.1582 & 0.3094 & 0.2681 \\
\hline II_fob & Total intermediate consumption & 0.5751 & 0.6609 & 0.7017 & 0.5965 \\
\hline GVA & Gross value added at basic prices & 0.4249 & 0.3391 & 0.2983 & 0.4035 \\
\hline VA & Net value added at basic prices & 0.3732 & 0.3165 & 0.2499 & 0.3649 \\
\hline GO & Output at basic prices & 1 & 1 & 1 & 1 \\
\hline
\end{tabular}

Table 2 shows the scale of the industry A01 operating in the referred countries. The Latvian A01 gross output volume 1804.75 means that the Latvian A01 has reserves to increase its gross output. Table 3 gives us the first signal about Latvian A01 inefficiency: the total intermediate consumption per monetary unit of gross output is sufficiently bigger than in EST, FIN, LTU, and as a result, the net value added is considerably smaller. What is the reason? We are going to examine the intermediate consumption in A01 in detail. Tables 4 and 5 contain general indicators about A01 product final demand allocation.

Table 4

Industry's A01 final demand in EST, FIN, LVA, LTU

\begin{tabular}{|c|c|c|c|c|c|c|c|c|}
\hline Code & Intermediate sales & CONS_h & CONS_np & CONS_g & GFCF & INVEN & EXP & GO \\
\hline EST & 616.56 & 263.36 & 0.09 & 0.10 & 28.50 & 74.86 & 239.72 & 1223.19 \\
\hline FIN & 4171.10 & 1080.02 & 0.02 & 8.66 & 62.09 & 30.49 & 1106.80 & 6459.17 \\
\hline LVA & 712.80 & 416.69 & 0.05 & 0.10 & 5.08 & -12.04 & 682.08 & 1804.75 \\
\hline LTU & 1253.09 & 396.14 & 0.00 & 0.13 & 96.71 & -34.41 & 1754.84 & 3466.50 \\
\hline
\end{tabular}

Code and Description:

CONS_h (Final consumption expenditure by households); CONS_g (Final consumption expenditure by government); CONS_np (Final consumption expenditure by non-profit organisations serving households (NPISH)); GFCF (Gross fixed capital formation); INVEN (Changes in inventories and valuables); EXP (Exports); GO (Gross output).

Table 5 puts forward the question about huge dissimilarity of the indicator CONS_g in EST, LVA, LTU when compared with the corresponding indicator in FIN (13 times higher). In order to explain the difference, further examination is needed.

Table 5

Industry's A01 final demand in EST, FIN, LVA, LTU with respect to monetary unit of output

\begin{tabular}{|c|c|c|c|c|c|c|c|c|}
\hline Code & Intermediate sales & CONS_h & CONS_np & CONS_g & GFCF & INVEN & EXP & GO \\
\hline EST & 0.5041 & 0.2153 & 0.0001 & 0.0001 & 0.0233 & 0.0612 & 0.1960 & 1 \\
\hline FIN & 0.6458 & 0.1672 & 0.0000 & 0.0013 & 0.0096 & 0.0047 & 0.1714 & 1 \\
\hline LVA & 0.3950 & 0.2309 & 0.0000 & 0.0001 & 0.0028 & -0.0067 & 0.3779 & 1 \\
\hline LTU & 0.3615 & 0.1143 & 0.0000 & 0.0000 & 0.0279 & -0.0099 & 0.5062 & 1 \\
\hline
\end{tabular}


Figure 1 depicts dynamics of export. The small EXP and big INVEN in EST and FIN in our turn witness about socio-economic orientation of Finland's A01, what does not qualify for significant A01 product exporter.

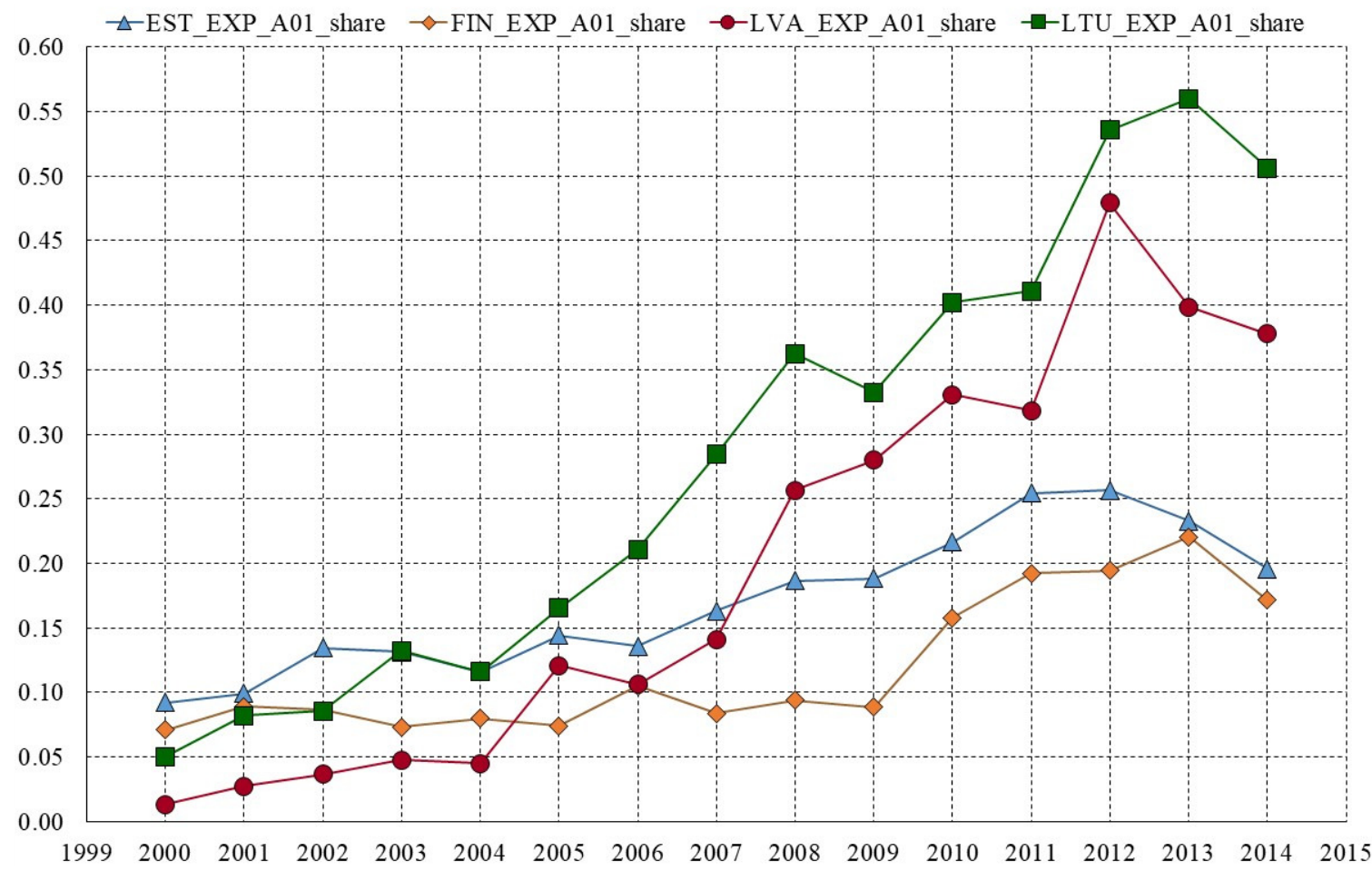

Fig 1. Exports of industry A01 as share of A01 gross output

2. Dynamics of the industry's A01 value added as part of gross output in EST, FIN, LVA, LTU (2000-2014).

Figure 2 depicts the time series of industry's A01 value added as part of gross output in EST, FIN, LVA, LTU for the period 2000-2014. Our attention is focused on the Latvian graph with its decreasing shape.

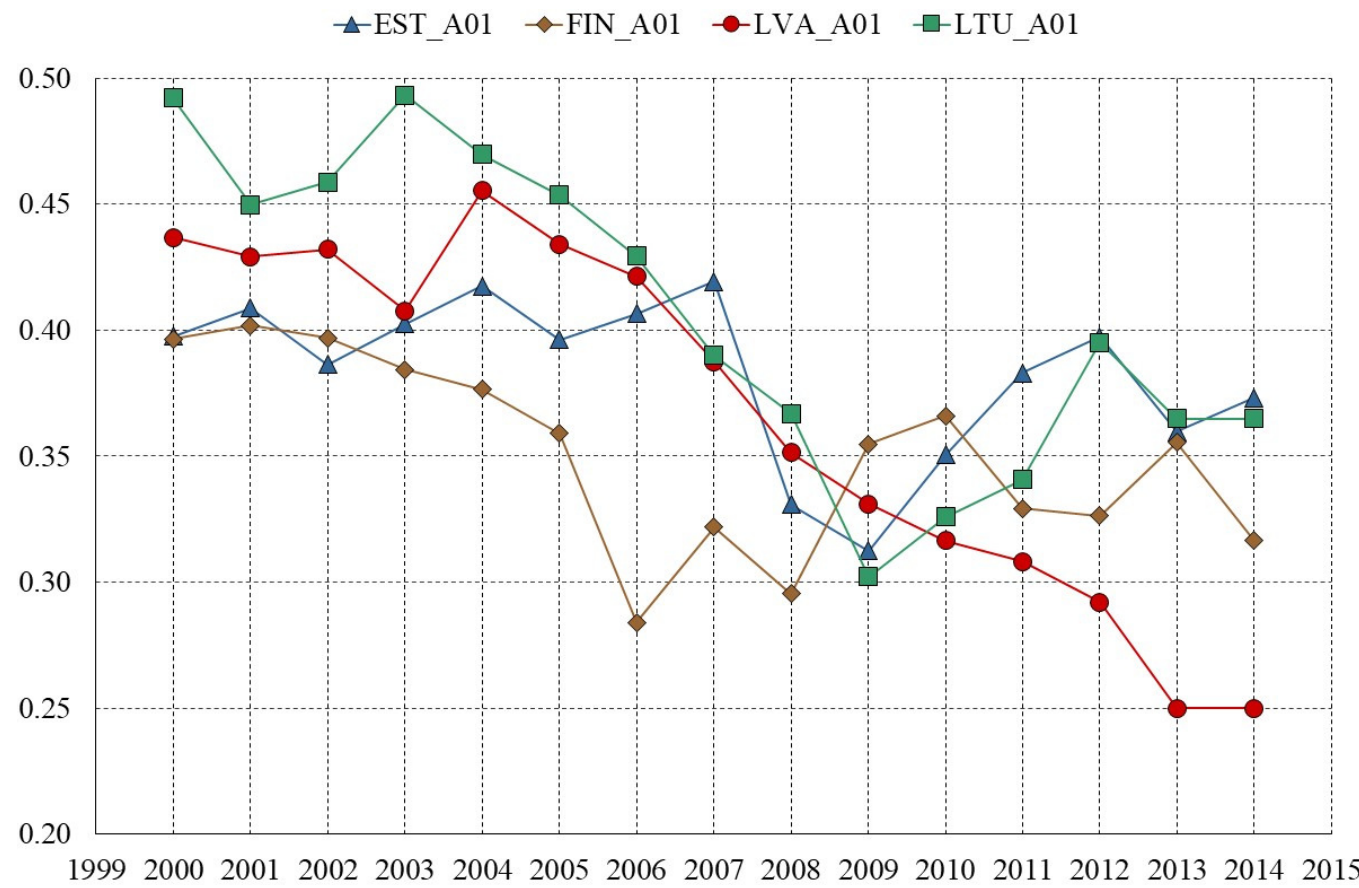

Fig. 2. Dynamics of A01 value added as part of gross output in EST, FIN, LVA, LTU in 2000-2014 
Figure 3 depicts the trends in a functional form $v=a \cdot \tau^{b}+c$ for each of time series for the latest six years (2009-2014). With help of such trends we classify the shape of dynamics of A01 value added of four types: increasing convex, increasing concave, decreasing convex, decreasing concave (Table 6). The comparative approach allows us to recognize sufficient differences in the shape of value added trends in the industry A01 in different countries.

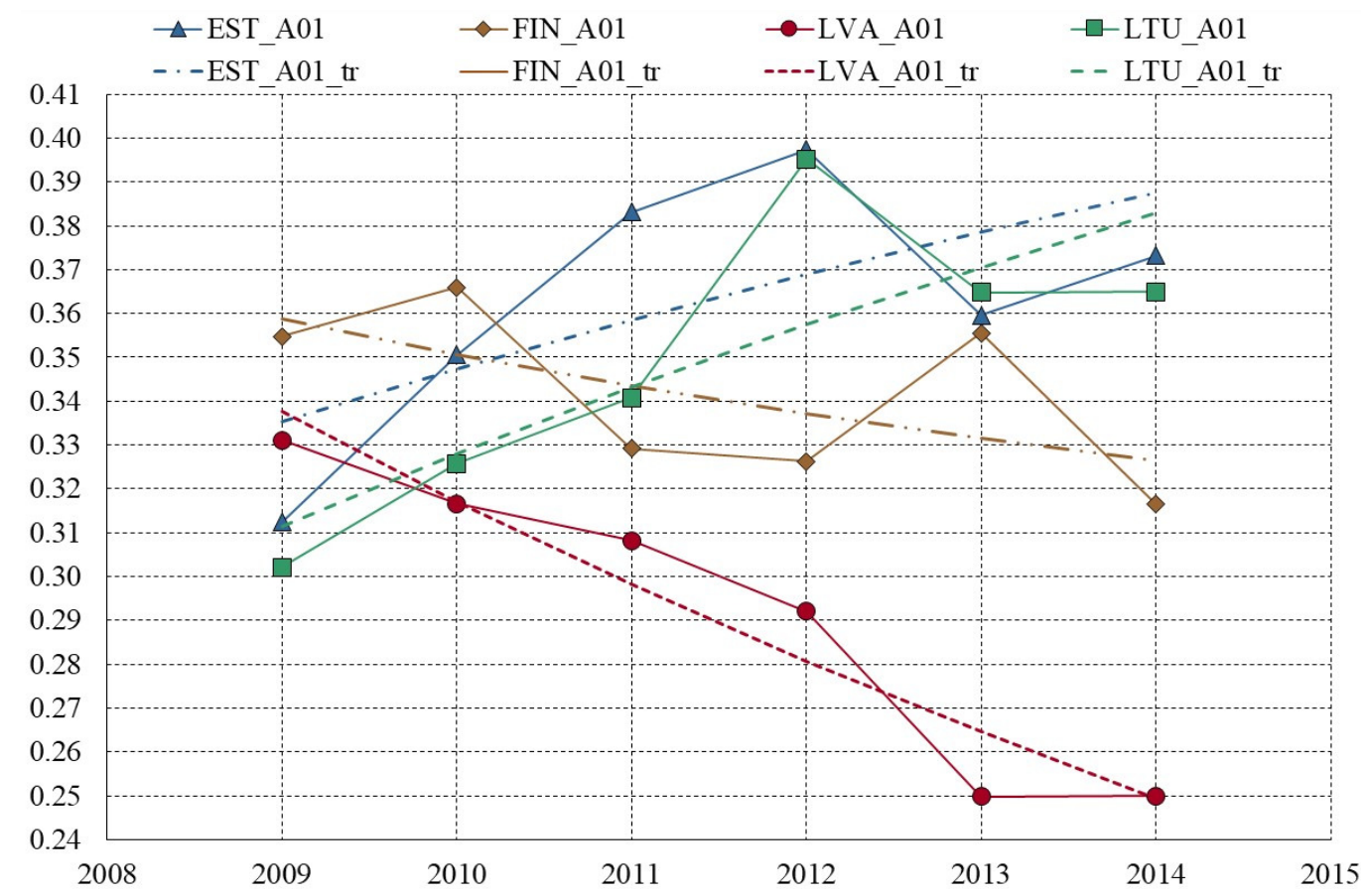

Fig. 3. Trends in functional form $v=a \cdot \tau^{b}+c$ for value added as part of gross output time series for latest six years (2009-2014)

Table 6

Trend lines in the functional form $v=a \cdot \tau^{b}+c, \tau=t-1998, t \in[2009$ 2014]. Value of the derivative $v^{\prime}=a \cdot b \cdot \tau^{b-1}$ in 2014

\begin{tabular}{|c|c|c|c|c|c|c|c|}
\hline A01 & a & b & c & $\uparrow$ or $\downarrow$ & $\cap$ or $\cup$ & v' (2014) & v' (2014) \\
\hline EST & 16.39 & 0.01 & -16.39 & increasing & concave & -0.0048 & -0.0005 \\
\hline FIN & 0.66 & -0.58 & 0.19 & decreasing & convex & -0.0004 & 0.0005 \\
\hline LVA & 16.98 & -0.01 & -16.07 & decreasing & convex & -0.0147 & 0.0009 \\
\hline LTU & 14.45 & 0.01 & -14.59 & increasing & concave & 0.0119 & -0.0007 \\
\hline
\end{tabular}

\section{Comparison and analysis of intermediate consumption}

Table 7 contains two arranged (from largest to smallest) excerpts from the total A01 intermediate consumption matrix (2014): arrangement by LVA indicators and arrangement by FIN indicators. We can observe total distinction in the ten biggest total intermediate consumptions (domestic plus imported purchases) per monetary unit of total output. In order to explain the difference, further examination is needed.

We state the Latvian A01 sufficiently bigger intermediate consumption (when compared with the referred countries) of products of the following industries: A01 (Crop and animal production, hunting and related service activities), C19 (Manufacture of coke and refined petroleum products), D35 (Electricity, gas, steam and air conditioning supply), C33 (Repair and installation of machinery and equipment).

Let us compare Figures 4 and 5. These figures show a significant fact. Opposite to EST and especially to FIN, Latvian A01 uses many products of A01 instead of the products of C10-C12 (Manufacture of food products, beverages and tobacco products). The biggest intermediate consumption with respect to A01 monetary unit of gross output in FIN is related to C10-C12 (0.1244). By opinion of the authors, more $\mathrm{C} 10-\mathrm{C} 12$ and less A01 - this indicates modern agro-business. 
Industry's A01 seven biggest input (domestic plus imported) indicators in LVA and FIN (2014) (components of the vectors $A_{{ }_{j}}:=D_{\cdot j}+M_{\cdot j}$ )



Fig. 4. Dynamics of A01 (Crop and animal production, hunting and related service activities) product intermediate consumption as part of A01 one monetary unit gross output

Figures $6,7,8$ depict the time series of above intermediate consumption per monetary unit of gross output.

Fig. 7 shows the sufficient differences in the intermediate expenses relating to D35 (Electricity, gas, steam and air conditioning supply). In LVA intermediate product cost of the D35 is 0.0375 with respect to one monetary unit of gross output. At the same time, in EST this indicator is 0.0258 , in FIN it equals to 0.0226, in LTU - 0.0158. This is a bad sign for Latvian A01 competitive power.

Fig. 8 shows the A01 intermediate expenses relating to C33 (Repair and installation of machinery and equipment). What is the explanation for the fact that intermediate consumption of the product of C33 (Repair and installation of machinery and equipment) in 2014 in LVA is about two times bigger than in other referred countries? This requires further examination together with industry A01 and C33 experts.

The direct backward linkages summarize the results of intermediate average costs investigation. The average costs with respect to one monetary unit of gross output is the highest for Latvian A01, namely, in 2014 this indicator is 0.7017 . In the same time DBL(EST, A01, 2014) $=0.5751$; DBL(FIN, $\mathrm{A} 01,2014)=0.6609 ; \mathrm{DBL}(\mathrm{LTU}, \mathrm{A} 01,2014)=0.5965$. 


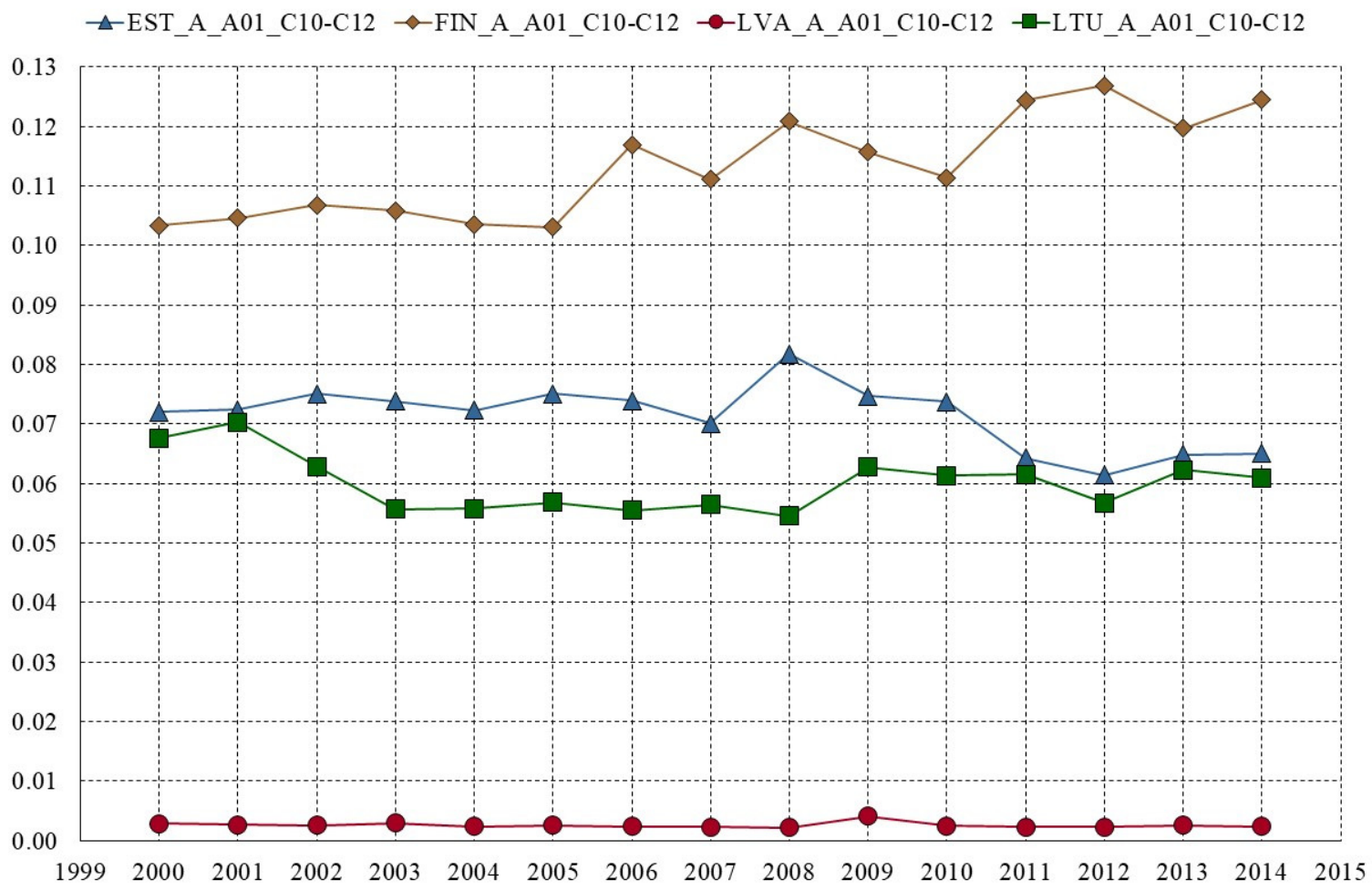

Fig. 5. Dynamics of industry's C10-C12 (Manufacture of food products, beverages and tobacco products) product intermediate consumption as part of A01 one monetary unit gross output

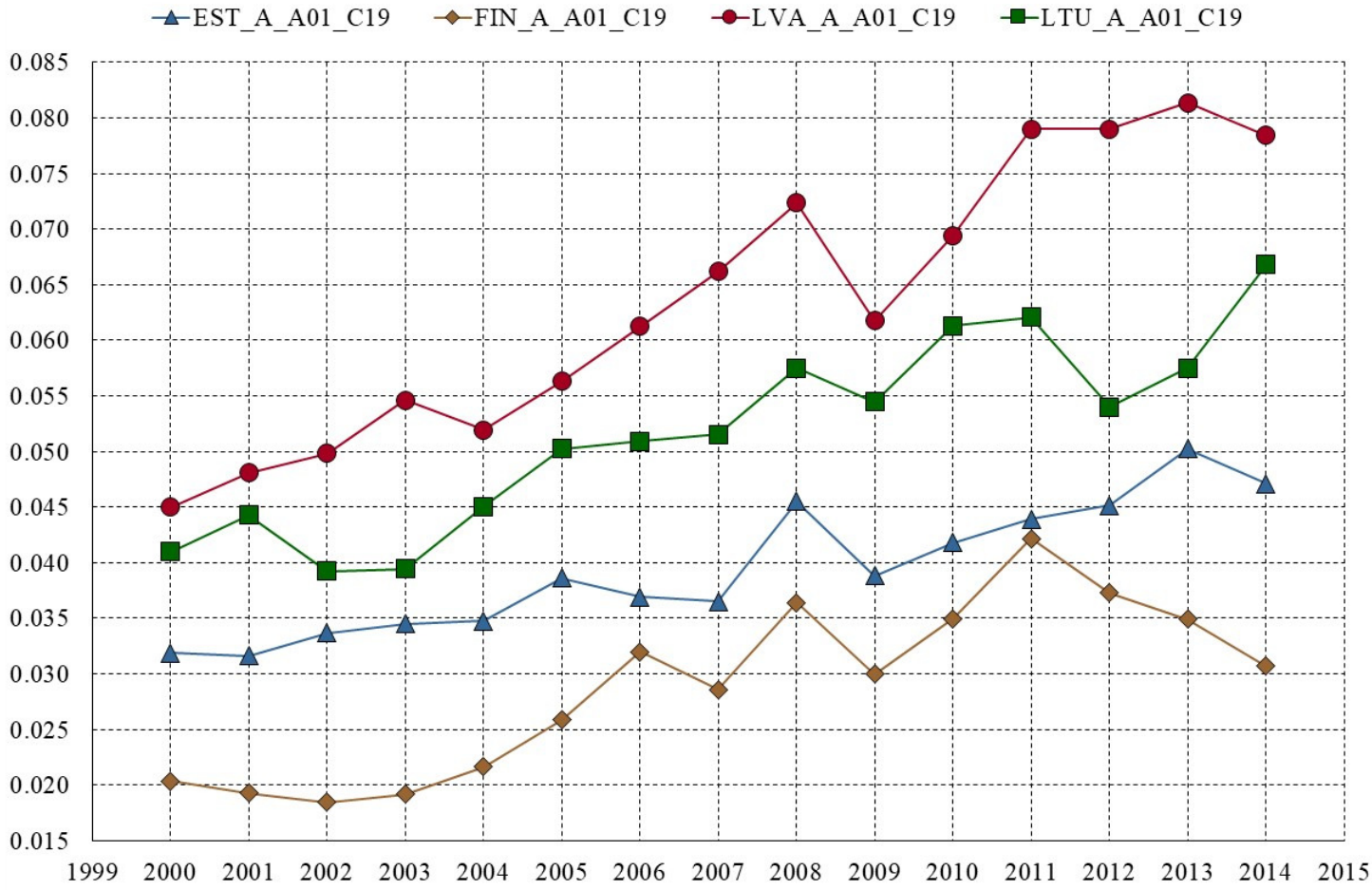

Fig. 6. Dynamics of industry's C19 (Manufacture of coke and refined petroleum products) product intermediate consumption as part of A01 one monetary unit gross output 


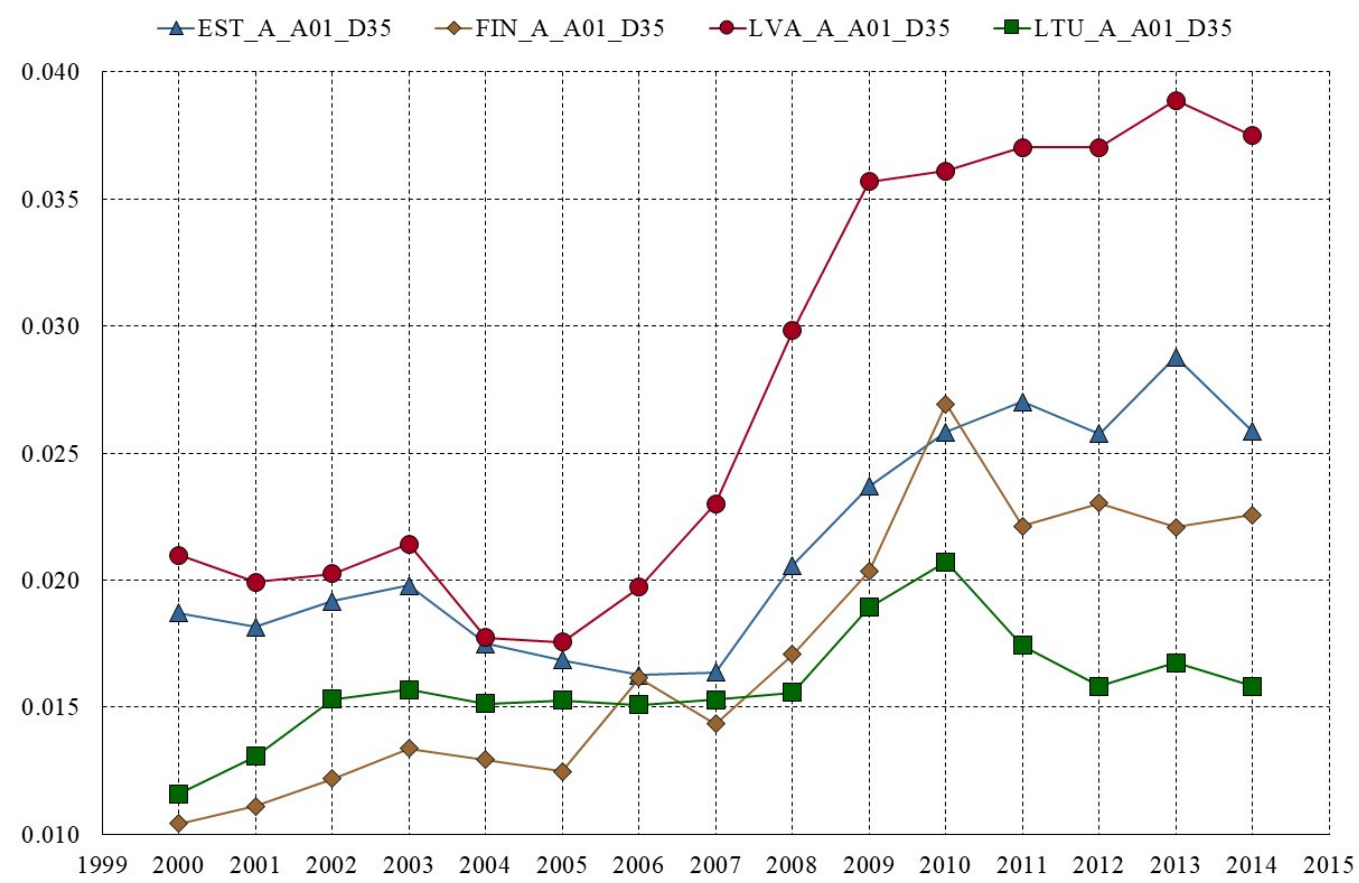

Fig. 7. Dynamics of industry's D35 (Electricity, gas, steam and air conditioning supply) product intermediate consumption as part of A01 one monetary unit gross output

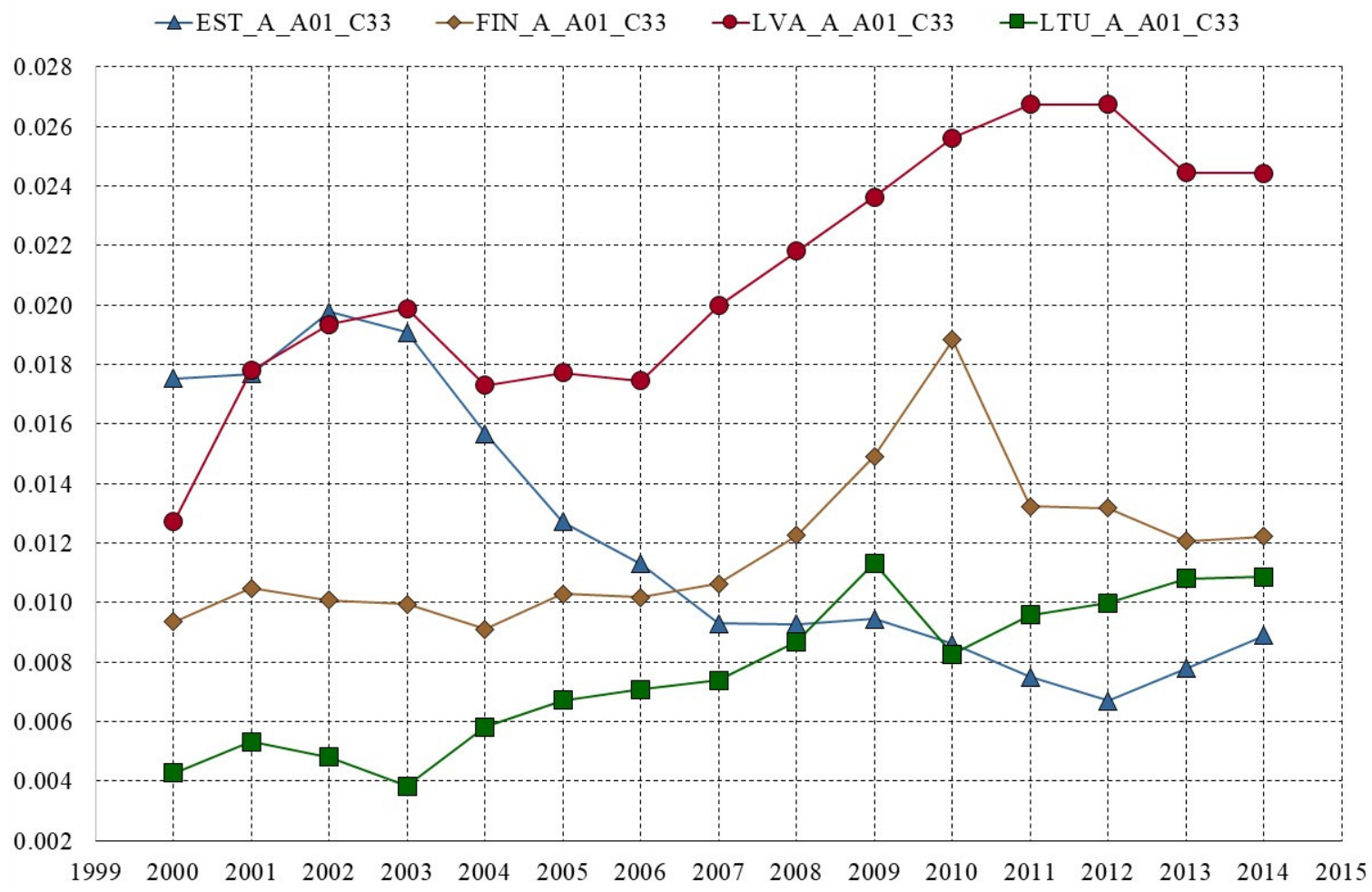

Fig. 8. Dynamics of industry's C33 (Repair and installation of machinery and equipment) product intermediate consumption as part of A01 one monetary unit gross output

\section{Comparison and analysis of allocation coefficients}

Table 8 contains two arranged (from largest to smallest) excerpts from the allocation matrices G: arrangement by LVA indicators and arrangement by FIN indicators. We can observe differences among the ten biggest buyers of A01 product. It is worth to investigate the reason of the difference between direct forward linkages in LVA and FIN: DFL(LVA, A01, 2014) $=0.3950$; DFL(FIN, A01, $2014)=0.6458$. For example, the FIN industry I (Accommodation and food service activities) buys 
$2.7 \%$ of domestic A01 gross output, while LVA industry I buys only $0.3 \%$. Apparently, EST with its $2.0 \%$ moves in the FIN direction. Further investigation is needed together with industry A01 and I experts in order to clarify the PESTILB environment and to elaborate upgraded management decisions.

Table 8

Industry's A01 ten biggest allocation coefficients for LVA and FIN (components of the vectors $G_{j}$.)

\begin{tabular}{|c|c|c|c|c|c|c|c|c|c|c|}
\hline Code & A01 & $\begin{array}{c}\text { C10- } \\
\text { C12 }\end{array}$ & C20 & I & C16 & D35 & $\begin{array}{c}\text { R_S + } \\
\text { T + U }\end{array}$ & G47 & G46 & F \\
\hline EST & 0.1386 & 0.3066 & 0.0003 & 0.0198 & 0.0074 & 0.0001 & 0.0019 & 0.0015 & 0.0004 & 0.0009 \\
\hline FIN & 0.0992 & 0.4295 & 0.0045 & 0.0271 & 0.0008 & 0.0012 & 0.0027 & 0.0027 & 0.0028 & 0.0045 \\
\hline LVA & $\mathbf{0 . 1 9 9 1}$ & $\mathbf{0 . 1 5 1 4}$ & $\mathbf{0 . 0 2 9 6}$ & $\mathbf{0 . 0 0 2 9}$ & $\mathbf{0 . 0 0 2 4}$ & $\mathbf{0 . 0 0 1 8}$ & $\mathbf{0 . 0 0 0 8}$ & $\mathbf{0 . 0 0 0 7}$ & $\mathbf{0 . 0 0 0 6}$ & $\mathbf{0 . 0 0 0 6}$ \\
\hline LTU & 0.0328 & 0.2932 & 0.0248 & 0.0009 & 0.0000 & 0.0000 & 0.0004 & 0.0001 & 0.0005 & 0.0001 \\
\hline
\end{tabular}

\begin{tabular}{|c|c|c|c|c|c|c|c|c|c|c|}
\hline Code & $\begin{array}{c}\text { C10- } \\
\text { C12 }\end{array}$ & A01 & I & C22 & Q & L68 & O84 & N & P85 & C20 \\
\hline EST & 0.3066 & 0.1386 & 0.0198 & 0.0001 & 0.0015 & 0.0009 & 0.0017 & 0.0023 & 0.0023 & 0.0003 \\
\hline FIN & $\mathbf{0 . 4 2 9 5}$ & $\mathbf{0 . 0 9 9 2}$ & $\mathbf{0 . 0 2 7 1}$ & $\mathbf{0 . 0 1 0 2}$ & $\mathbf{0 . 0 0 9 8}$ & $\mathbf{0 . 0 0 8 9}$ & $\mathbf{0 . 0 0 7 2}$ & $\mathbf{0 . 0 0 5 9}$ & $\mathbf{0 . 0 0 4 7}$ & $\mathbf{0 . 0 0 4 5}$ \\
\hline LVA & 0.1514 & 0.1991 & 0.0029 & 0.0000 & 0.0004 & 0.0004 & 0.0004 & 0.0006 & 0.0004 & 0.0296 \\
\hline LTU & 0.2932 & 0.0328 & 0.0009 & 0.0000 & 0.0011 & 0.0000 & 0.0000 & 0.0000 & 0.0001 & 0.0248 \\
\hline
\end{tabular}

\section{Comparison and analysis of the impact of A01 final demand increase on the total output} required for equilibrium in the national economy

Table 9 contains two arranged (from largest to smallest) excerpts from the Leontief inverse $\boldsymbol{\Lambda}$ : arrangement by LVA indicators and arrangement by FIN indicators. We can observe sufficient distinction in the national industries' necessary reaction to the A01 final demand increase in order to provide economic equilibrium in the national economy. For example, as it was expected, in LVA the biggest pressure is related to the pitifully famous Latvian industry D35 (Electricity, gas, steam and air conditioning supply). In LVA it is more than two times bigger than in the other referred countries.

Surprisingly, the Latvian A01 final demand increase shows impact of 0.0593 to the industry H52 (Warehousing and support activities for transportation) when compared with $0.0148 ; 0.0181 ; 0.0248$ in EST, FIN and LTU.

Industry's A01 twelve biggest Leontief coefficients for LVA and FIN

Table 9 (components of the vectors $\Lambda_{j}$.)

\begin{tabular}{|c|c|c|c|c|c|c|c|c|c|}
\hline Code & EST & FIN & LVA & LTU & Code & EST & FIN & LVA & LTU \\
\hline A01 & 1.1714 & 1.1453 & $\mathbf{1 . 2 5 0 2}$ & 1.0387 & A01 & 1.1714 & $\mathbf{1 . 1 4 5 3}$ & 1.2502 & 1.0387 \\
\hline D35 & 0.0382 & 0.0355 & $\mathbf{0 . 0 7 7 9}$ & 0.0206 & C10-C12 & 0.0528 & $\mathbf{0 . 1 6 5 8}$ & 0.0020 & 0.0228 \\
\hline H52 & 0.0148 & 0.0181 & $\mathbf{0 . 0 5 9 3}$ & 0.0248 & G46 & 0.0101 & $\mathbf{0 . 0 7 2 4}$ & 0.0566 & 0.0808 \\
\hline G46 & 0.0101 & 0.0724 & $\mathbf{0 . 0 5 6 6}$ & 0.0808 & N & 0.0114 & $\mathbf{0 . 0 5 4 1}$ & 0.0167 & 0.0117 \\
\hline C33 & 0.0133 & 0.0186 & $\mathbf{0 . 0 3 4 3}$ & 0.0140 & C20 & 0.0030 & $\mathbf{0 . 0 5 1 6}$ & 0.0055 & 0.0192 \\
\hline K64 & 0.0151 & 0.0230 & $\mathbf{0 . 0 2 3 5}$ & 0.0109 & F & 0.0153 & $\mathbf{0 . 0 3 9 8}$ & 0.0128 & 0.0136 \\
\hline H49 & 0.0209 & 0.0191 & $\mathbf{0 . 0 2 2 8}$ & 0.0239 & D35 & 0.0382 & $\mathbf{0 . 0 3 5 5}$ & 0.0779 & 0.0206 \\
\hline A02 & 0.0010 & 0.0058 & $\mathbf{0 . 0 1 8 7}$ & 0.0036 & G45 & 0.0163 & $\mathbf{0 . 0 3 1 1}$ & 0.0047 & 0.0128 \\
\hline N & 0.0114 & 0.0541 & $\mathbf{0 . 0 1 6 7}$ & 0.0117 & K64 & 0.0151 & $\mathbf{0 . 0 2 3 0}$ & 0.0235 & 0.0109 \\
\hline L68 & 0.0228 & 0.0155 & $\mathbf{0 . 0 1 6 3}$ & 0.0215 & C19 & 0.0061 & $\mathbf{0 . 0 2 2 4}$ & 0.0017 & 0.0334 \\
\hline G47 & 0.0881 & 0.0101 & $\mathbf{0 . 0 1 6 1}$ & 0.0211 & H49 & 0.0209 & $\mathbf{0 . 0 1 9 1}$ & 0.0228 & 0.0239 \\
\hline K66 & 0.0018 & 0.0064 & $\mathbf{0 . 0 1 5 1}$ & 0.0002 & C33 & 0.0133 & $\mathbf{0 . 0 1 8 6}$ & 0.0343 & 0.0140 \\
\hline TBL & 1.5849 & 1.9144 & $\mathbf{1 . 6 9 2 1}$ & 1.4499 & & & & & \\
\cline { 1 - 3 } & & & & & & & &
\end{tabular}


Tables 10 and 11 show that in EST, LVA, LTU the industry A01 has to be qualified as an industry with medium total backward linkage. This conclusion is important, because it indicates a medium impact on the rest national industries caused by an increase in the final demand in A01. In FIN the industry A01 has the indicator TBL(FIN, A01, 2014) = 1.91. Namely, if the Latvian industry A01 is able to increase its final demand when all other industries final products remain unchanged, the required balanced growth of all rest national industries gross outputs in order to ensure economic equilibrium is not unrealistic.

Table 10

LVA industries with twelve biggest total backward linkages (TBL) and industries with twelve smallest total backward linkages

\begin{tabular}{|c|c|c|c|c|c|c|c|c|c|c|c|c|}
\hline Code & H52 & C19 & C16 & D35 & F & H51 & M73 & A02 & K65 & H49 & G46 & J58 \\
\hline
\end{tabular}

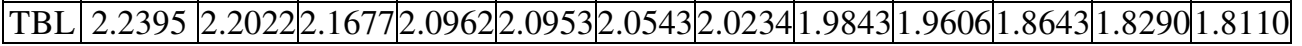

\begin{tabular}{|c|c|c|c|c|c|c|c|c|c|c|c|}
\hline Code J62_J63 & O84 & C29 & C28 & C17 & C22 & C27 & C25 & C26 & P85 & Q & M72 \\
\hline
\end{tabular}

\begin{tabular}{l|l|l|l|l|l|l|l|l|l|l|l|l|l|}
\hline TBL & 1.4632 & 1.4436 & 1.4372 & 1.4203 & 1.3891 & 1.3765 & 1.3762 & 1.3351 & 1.3344 & 1.3150 & 1.2958 & 1.1499 \\
\hline
\end{tabular}

FIN industries with twelve biggest total backward linkages (TBL) and industries with twelve smallest total backward linkages

\begin{tabular}{|l|c|c|c|c|c|c|c|c|c|c|c|}
\hline CodeC10-C12 & C16 & C17 & H52 & H51 & A01 & I & C24 & C18 & F & J58 & M74_M75 \\
\hline TBL 2.2358 & 2.1191 & 2.0941 & 2.0621 & 2.0458 & $\mathbf{1 . 9 1 4 4}$ & 1.8941 & 1.8873 & 1.8468 & 1.8024 & 1.7662 & 1.7647 \\
\hline
\end{tabular}

\begin{tabular}{|c|c|c|c|c|c|c|c|c|c|c|c|c|}
\hline Code & C29 & K65 & C13-C15 & C19 & Q & L68 & E36 & P85 & A02 & M72 & C21 & A03 \\
\hline TBL & 1.5067 & 1.4940 & 1.4719 & 1.4568 & 1.4458 & 1.4306 & 1.4151 & 1.3519 & 1.3388 & 1.3243 & 1.3161 & 1.2480 \\
\hline
\end{tabular}

6. Comparison and analysis of the impact of A01 value added increase on the total output required for equilibrium in the national economy

Table 12 contains two arranged (from largest to smallest) excerpts from the Ghosh inverse $\Gamma$ : arrangement by LVA indicators and arrangement by FIN indicators.

Industry's A01 ten biggest Gosh coefficients for LVA and FIN

Table 12 (components of the vectors $\Gamma_{j}$.)

\begin{tabular}{|c|c|c|c|c|c|c|c|c|c|c|c|}
\hline Code & A01 & $\begin{array}{c}\text { C10- } \\
\text { C12 }\end{array}$ & C20 & I & C16 & D35 & F & G46 & N & $\begin{array}{c}\text { R_S + } \\
\text { T + U }\end{array}$ & TFL \\
\hline EST & 1.1714 & 0.4007 & 0.0022 & 0.0422 & 0.0163 & 0.0014 & 0.0043 & 0.0035 & 0.0052 & 0.0044 & 1.7145 \\
\hline FIN & 1.1453 & 0.6138 & 0.0246 & 0.0939 & 0.0055 & 0.0065 & 0.0256 & 0.0142 & 0.0196 & 0.0155 & 2.2346 \\
\hline LVA & $\mathbf{1 . 2 5 0 2}$ & $\mathbf{0 . 2 0 8 1}$ & $\mathbf{0 . 0 3 7 5}$ & $\mathbf{0 . 0 1 0 1}$ & $\mathbf{0 . 0 0 5 2}$ & $\mathbf{0 . 0 0 4 7}$ & $\mathbf{0 . 0 0 4 2}$ & $\mathbf{0 . 0 0 2 5}$ & $\mathbf{0 . 0 0 2 0}$ & $\mathbf{0 . 0 0 1 9}$ & $\mathbf{1 . 5 4 6 4}$ \\
\hline LTU & 1.0387 & 0.3114 & 0.0273 & 0.0024 & 0.0002 & 0.0001 & 0.0005 & 0.0013 & 0.0002 & 0.0008 & 1.3990 \\
\hline
\end{tabular}

\begin{tabular}{|c|c|c|c|c|c|c|c|c|c|c|}
\hline Code & A01 & $\begin{array}{c}\text { C10- } \\
\text { C12 }\end{array}$ & I & Q & F & C20 & O84 & L68 & N & C17 \\
\hline EST & 1.1714 & 0.4007 & 0.0422 & 0.0035 & 0.0043 & 0.0022 & 0.0043 & 0.0025 & 0.0052 & 0.0011 \\
\hline FIN & $\mathbf{1 . 1 4 5 3}$ & $\mathbf{0 . 6 1 3 8}$ & $\mathbf{0 . 0 9 3 9}$ & $\mathbf{0 . 0 3 4 6}$ & $\mathbf{0 . 0 2 5 6}$ & $\mathbf{0 . 0 2 4 6}$ & $\mathbf{0 . 0 2 4 3}$ & $\mathbf{0 . 0 2 3 0}$ & $\mathbf{0 . 0 1 9 6}$ & $\mathbf{0 . 0 1 6 3}$ \\
\hline LVA & 1.2502 & 0.2081 & 0.0101 & 0.0015 & 0.0042 & 0.0375 & 0.0013 & 0.0015 & 0.0020 & 0.0001 \\
\hline LTU & 1.0387 & 0.3114 & 0.0024 & 0.0019 & 0.0005 & 0.0273 & 0.0003 & 0.0001 & 0.0002 & 0.0001 \\
\hline
\end{tabular}

The content of Table 12 confirms, from another point of view, the conclusion made before on the basis of Tables 10 and 11: EST, FIN, LVA, LTU have to be qualified as industry with medium total forward linkage: TFL $(E S T, A 01,2014)=1.71 ; \operatorname{TFL}(L V A, A 01,2014)=1.55 ; \operatorname{TFL}(L T U, A 01$, 2014) $=1.40$.

That conclusion indicates a medium impact on the rest national industries caused by the value added increase in A01. Namely, if the industry A01 is able to increase its value added when value 
added of all the other industries remains unchanged, the required balanced growth of all the rest national industries gross outputs to ensure economic equilibrium is not unrealistic and can be attained.

\section{Conclusions}

1. The comparative analysis of value added created by the industry A01 (Crop and animal production, hunting and related service activities) with respect to gross output in the Baltic States and Finland in the period of 2000-2014 clearly demonstrates the comparative inefficiency of Latvian industry A01.

2. The economic analysis leads to the two most important 'roots' of the inefficiency of the Latvian industry A01: (a) considerably higher intermediate costs per monetary unit of gross output; (b) inefficient allocation the product of A01 in the domestic economy.

3. The rigorous analysis of the Latvian A01 product average costs and product allocation in the domestic economy compared with EST, FIN, LTU would be useful.

4. One of the possible tools to increase value added in the Latvian A01 is expanding the exports, because the final demand increase in A01 requires moderate conditions to the rest national economy.

5. Further investigation is needed together with industry A01 experts and must be oriented towards explaining the most essential differences between the line of indicators in order to clarify PESTILB environment and elaborate upgraded management decisions.

\section{References}

[1] Leontief W. Input-Output Economics. Second Edition. - Oxford University Press. 1986, $436 \mathrm{pp}$.

[2] Ghosh A. Input-Output Approach to an Allocation System. - Economica, Vol. 25, No. 1, 1958, pp. 58-64.

[3] Ronald E. Miller, Peter D. Blair. Input-Output analysis. Foundations and extensions. Second Edition. - Cambridge University Press, 2013, 750 pp.

[4] Rose, A., Miernyk, W. (1989). Input-output analysis: the first fifty years. Economic Systems Research, 1(2), 229-272.

[5] Thijs ten Raa. (2019). The use-make framework and the derivation of functional forms in production theory. Economic Systems Research, vol. 31, NO 1, 132-141.

[6] Pilvere I., Krievina A., Nipers A. Projecting value added in agriculture in Latvia. 17th International Scientific Conference on Engineering for Rural Development, Proceedings, Volume 17, Jelgava, Latvia, 23 - 25 May, 2018, pp. 1084-1090. DOI: 10.22616/ERDev2018.17.N151

[7] Ashyrov G., Paas T., Tverdostup M. The Input-Output analysis of blue industries: comparative study of Estonia and Finland. University of Tartu. Faculty of Social Sciences. School of Economics and Business Administration, 2018. 25 p. [online] [20.03.2018]. Available at: https://majandus.ut.ee/en/research/workingpapers

[8] Jaunzems A. Comparative dynamic analysis of value added created by industry "forestry and logging" in the Baltic states and Finland. 17th International Scientific Conference on Engineering for Rural Development. Proceedings, Latvia, Jelgava, 2018, pp. 1019-1028.

[9] European Central Bank. All glossary entries - V. [online][16.02.2019] Available at: http://www.ecb.europa.eu/home/glossary/html/glossv.en.html.

[10]Eurostat. Intermediate consumption. [online][16.02.2019] Available at: http://epp.eurostat.ec.europa.eu/statistics_explained/index.php/Glossary:Intermediate_consumptio n.

[11]Eurostat. Gross value added. [online][16.02.2019] Available at: http://epp.eurostat.ec.europa.eu/statistics_explained/index.php/Glossary:Gross_value_added. 